\title{
Intermédialités
}

Histoire et théorie des arts, des lettres et des techniques

Intermediality

History and Theory of the Arts, Literature and Technologies

\section{Phantasia and Technè at the Fin-de-siècle}

\section{William Uricchio}

Numéro 6, automne 2005

Remédier

Remediation

URI : https://id.erudit.org/iderudit/1005504ar

DOI : https://doi.org/10.7202/1005504ar

Aller au sommaire du numéro

Éditeur(s)

Centre de recherche sur l'intermédialité

ISSN

1705-8546 (imprimé)

1920-3136 (numérique)

Découvrir la revue

Citer cet article

Uricchio, W. (2005). Phantasia and Technè at the Fin-de-siècle. Intermédialités /

Intermediality, (6), 27-42. https://doi.org/10.7202/1005504ar
Résumé de l'article

Cet article propose une réévaluation — sur un plan théorique et historique du télévisuel. L'auteur avance l'hypothèse suivant laquelle le télévisuel offre un moyen d'élargir l'appréhension et l'interaction du spectateur avec le monde, à la différence d'autres médias, tels le cinéma, la photographie ou la musique enregistrée qui ne peuvent pas offrir l'expérience du « direct » et de la simultanéité. Il s'intéresse non seulement à la question du développement technologique des médias et à la différence ontologique entre les médias, mais également au problème épistémologique plus vaste que pose la technologie dans notre compréhension de la modernité. À partir des analyses husserliennes et heideggeriennes sur la relation entre technè et modernité, cet étude se penche sur l'histoire de la télévision nazie et, entre autres choses, explore les dichotomies sujet-objet et présence-représentation. 


\title{
Phantasia and Technè at the Fin-de-siècle
}

\author{
William URicchio
}

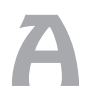

11 too often, our media histories have tended to flatten time-based (moving)

image media into a coherent genealogy. Beginning with the ability to "capture" and "store" the photographic image in the early 19th century, dominant historical narratives move through various mechanical technologies capable of creating the illusion of motion, and culminate in the combination of these two practices with the projections of the Lumiere brothers in 1895. Television has generally been sutured into this genealogy, and positioned as something of a motion picture derivative, the inheritor of a particular notion of time-based imagery. Although technologically distinct, television's optical systems, "frame-rate," and storage potentials tend to be understood (and metaphorically positioned) as conceptually consistent with the late 19th century project of cinema. Seen from this perspective, television's specificity can be found in its locus as part of the domestic sphere, in its relatively low image resolution, and in its distinctive attribute of programming "flow." That our current implementation of the medium is dominated by certain programming forms-drama, sitcoms, soaps, documentaries, even sports-that all seem to owe their basic signifying practices to principles worked out in the film medium, seems both appropriate and natural. But the realities of the broadcast television era notwithstanding, there are good reasons to challenge this framing of the medium, reasons that go back to the earliest developments of the medium and even back to fantasies of moving image systems generally. ${ }^{1}$

In this essay, I'd like to argue for very different developmental trajectories underlying cinema and television. I'd like to explore the implications of this

1. This essay is part of a larger work: an investigation into what might broadly be called the televisual. The larger project explores the deep history of seeing at a distance and attempts to tease out some of the implications of the various media technologies and practices that have been deployed in its service. 
challenge to the dominant positioning of the media and suggest their relevance to both issues of intermediality and media ontology. In particular, I'd like to reconsider television's status as a medium and the larger issue of media genealogies as a way to tease out the links between media technologies and the larger epistemological regimes of which they are a part. To do this, I will need to take two unorthodox steps. First, I will largely bracket off our quotidian experience of television, that is to say the set of institutional broadcasting practices that have dominated from the early 1950s, focusing instead on a notion of "ideal-typical" television. Second, I will dwell on the potentials of imaginary technologies, of fantasies and forecasts, as a way of giving the argument substance. The goal of this endeavor has centrally to do with an assessment of the relationship of moving image technologies to modernity.

Although I will generally be referring to modernity in its narrow sense as a mid- to late-19th century phenomenon accompanied by urbanization and industrialization, I will also suggest the relevance of the questions I am asking to modernity in its broader sense as a movement associated with the Enlightenment and the new order of subject-object relations mapped out by, among others, René Descartes. Scholars such as Tom Gunning, Mary Ann Doane, Jonathan Crary, and Stephan Kern have, in different ways, demonstrated the rich interplay, both determining and determined, between 19th century image technologies (and film in particular) and modernity. ${ }^{2}$ As suggested by the work of an earlier generation of scholars, from Bergson to Benjamin, media-both as metaphors and substantives - have long been crucial to an understanding of modernity and our (modern) experience of the physical as well as cultural world. But at both ends of the zoth century, our consideration of this interdependency has always been tempered by the variability inscribed within the term (and experience of) modernity. Throughout this period, many critics-myself included-have tended to understand modernity with the aid of Baudelaire's triadic definition: the ephemeral,

2. See in particular Tom Gunning, "Phantasmagoria and the Manufacturing of Illusions and Wonder: Towards a Cultural Optics of the Cinematic Apparatus," in André Gaudreault, Catherine Russell, Pierre Veronneau (eds.), The Cinema, A New Technology for the 20th Century, Lausanne, Éditions Payot, 2004, p. 31-44 and "An Aesthetic of Astonishment: Early Film and the [In]Credulous Spectator," Art and Text, No. 34, 1989, p. 31-45; Mary Ann Doane, The Emergence of Cinematic Time: Modernity, Contingency, the Archive, Cambridge, Massachusetts, Harvard University Press, 2002; Jonathan Crary, Techniques of the Observer: On Vision and Modernity in the Nineteenth Century, Cambridge, Massachusetts, MIT Press, 1990; Stephen Kern, The Culture of Time and Space, 1880-1918, Cambridge, Massachusetts, Harvard University Press, 2003 [1983]. 
the fugitive, and the contingent. ${ }^{3}$ This shared definitional framework has been productive, not the least because it has facilitated the accretion of insights and permitted a larger conversation about modernity. But there are other ways of defining modernity, ways that potentially throw into relief underappreciated aspects of certain media developments.

\section{REPOSITIONING THE MODERN}

In this essay, I'd like to make a heuristic shift from Baudelaire's insights to a different view, one more sensitive to notions of modernity bound up in technology and thus in media. For this, I will turn from the French to the Germans, that is, to Husserl and in particular Heidegger, considering what a very different perspective brings to the mix. For both philosophers, despite fundamental differences in approach, technology (or aspects thereof) bore heavily not only on the notion of modernity, but also on the nature of object-subject relations. More to the point, their thoughts on this topic help to raise-and potentially offer ways of answering-the question of whether we can distinguish between the larger epistemological regimes of which the film medium and the television medium were part.

In The Crisis of European Sciences (1936), Husserl pointed to modernity's defining crisis, a crisis bound up in the division between "physicalistic" objectivism and transcendental subjectivism. According to Husserl, this crisis was provoked by technicization (Technisierung), by a preoccupation with empty rules and abstractions rather than with deep sense making. 4 A "pathological" form of technè, 5 technicization privileged efficiency over meaningfulness-turning reality into a resource for possible worlds. ${ }^{6}$ Implicit in this critique of the modern, defined largely by the breakdown of object-subject relations, is a lament regarding the cultural loss brought about by the shift from the handmade to the

3. Charles Baudelaire, "Le peintre de la vie moderne" (Le Figaro, 1863), in Charles Harrison et al., Art in Theory, 1815-1900: An Anthology of Changing Ideas, Oxford, Blackwell Publishers, 1998, p. 498.

4. Edmund Husserl, The Crisis of European Sciences and Transcendental Phenomenology, trans. David Carr, Evanston, Northwestern University Press, 1970 [1936].

5. Technè can be defined as art, skill, the application of knowledge to a specific product, a system of making or doing something (although not in the sense of a manual skill or workshop behavior). Technè is a branch of knowledge, a form of practical wisdom (like philosophy or mathematics or, in pre-Enlightenment terms, magic).

6. Werner Rammert, "Relations that Constitute Technology and Media That Make a Difference: Toward a Social Pragmatic Theory of Technicization," Techné: Journal of the Society of Philosophy and Technology Vol. 4, No. 3, spring 1999, p. 23-43. 
readymade-a shift, as media scholars know all too well from the debates in the late 19th and early 2 oth centuries, resonant with the introduction of "soulless," "mechanical," "industrially-produced" representational technologies such as the cinema. Husserl was careful to insist that the problem was not technè, but rather its misuse. And implicit in his understanding of the defining crisis of modernity was the status of meaningfulness - something, as we will see, that sets him apart from Heidegger (for whom being was the defining concept). If the defining crisis of modernity for Husserl was technicization as a means for "turning reality into a resource for possible worlds," what would be at stake if we were to invert this formulation? What if we had the means for "turning possible worlds into resources for reality?" Might this offer us a way around this defining crisis of modernity? Might it provide a way to reconcile rather than to exacerbate the subject-object divide? Husserl's understanding of technology's characteristic deployment in modernity, his formulation of the relationship between the possible and the real, offers an entry point to considering the possible, the imaginary, or phantasia. More than fantasies as "mere" indications of a culture's desires or critiques, these extensions of the subject into articulated and inter-subjective forms potentially offer access into the deeper reaches of cultural perception, and may even provide a glimpse of world views that, while over-trodden by "real world" developments, remain indicators of a parallel mode of experience.

Technologies of seeing offer a particularly resonant site to consider, given that they literally broker and give form to the subject-object relations seen by Husserl and Heidegger as defining for the modern (writ large). If we turn to the telectroscope, telephonoscope, electronic camera obscura, and various related ideas (and technologies) regarding a moving image medium that proliferated between the introduction of the telephone in 1876 and the introduction of the filmed moving picture in 1895 , we might find more than simply historical access to a once hoped for future, valuable though that is. Their situation at a critical juncture in the emergence of the modern, and their capacities as both phantasia and technè to embody key elements in the debate over modernity, render them particularly resonant in their address of key aspects of the broader development of fin-de-siècle media. More to the point, they might offer insights into a now repressed notion of mediality, one superceded by the regime of the cinematic, but one that nevertheless seems persistent in our thinking about new media. How, then, should we read those early fantasies of televisual technologies that preceded the advent of film? As Husserl might, that is as signs of incipient degeneration, as a new force in the breakdown of subject-object relations, as evidence of a culture already on the skids? Or just the reverse, as an attempt to sustain the 


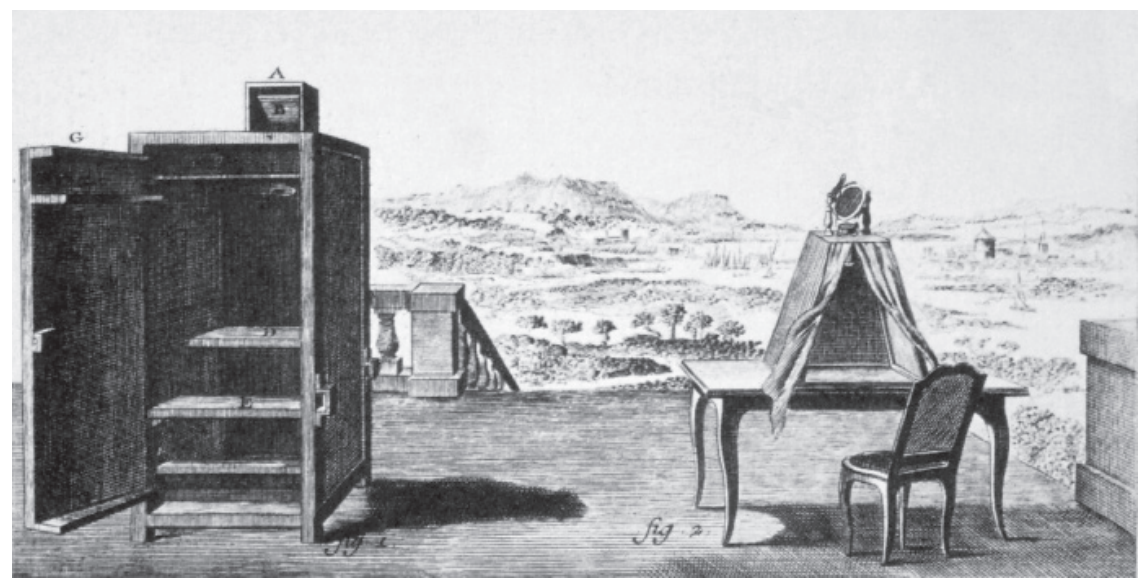

Fig. 1. First generation "presence machines:" two examples of a portable camera obscura (18th century).

old order of things in the face of assaults upon it, as an image of media technology - an imagination - that sought to bind together the viewing subject with the object seen, suturing any ruptures that might occur in a fast changing world? My contention is that late 19th century notions of the televisual, like their precedents in the form of the camera obscura, worked in the interest of this latter project. Moreover, these notions of the televisual turn on the concept of presence in ways that precisely distinguish them from the cinematic. Indeed, I would claim that these early discourses offer an insight into one of the long plastered-over fault lines between the modern and pre-modern eras. (Fig. 1)

\section{FRAMING STRATEGIES}

Let us first consider ways of reading these imagined (and sometimes technologized) moving image technologies from the pre-film era. I have elsewhere discussed an alternative to the unified genealogy of film and television, outlining the parallel histories of storage media (photography, phonograph and gramophone, the motion picture) and transmission media (telegraph, telephone, and television), both rooted in the media technologies of the first decades of the 19th century. ${ }^{7}$ Such a distinction offers a number of ways of thinking about the framings and meanings of moving image media.

7. William Uricchio, “Technologies of Time," in Jan Olsson and John Fullerton (eds.), Allegories of Communication: Intermedial Concerns from Cinema to the Digital, Eastleigh, John Libbey Publishing, 2004, p. 123-138. 
For example, we might take the just-mentioned imagined televisual technologies developed between 1876 and 1895-telectroscopes, telephonoscopes, and nameless ensembles of telephones, magic lanterns, batteries, gramophones, and the like-and see them as pre-cinematic fantasies of (projected or reflected) moving image technologies. In this sense, they offer access to a somewhat marginalized history of expectation that "paved the way" for the appearance of the film medium. Such fantasies - which were not only widespread but in some cases actually patented - offer a crucial way to re-frame our understanding of cinema's appearance as a medium, not so much in the sense of "predicting the future" as in providing a horizon of expectations against which the film medium was forced to position itself. They offer a way to locate the various technological models and experiential claims that helped to shape and give form to the film medium, suggesting a process of "remediation" in which the referenced media were imaginary. A somewhat differently pitched understanding of remediation could also lead to a reconsideration of the first decade of film production, suggesting a radical way to re-read early filmed actualités in the light of television, a medium for which the public was prepared and which at least some film producers arguably referenced in their practice. Only when the film industry gave up its dependence on the television-like actualités, and instead embraced what one trade paper called "canned drama," did the-to our eyes-familiar use of the film medium appear. This heavily overdetermined moment of change-coincident with a transformation of film content (the dominance of the story film), distribution (the appearance of the exchange or film rental system), exhibition (the nickelodeon or permanent cinema), and audiences (massive expansion) - set the stage for the notion of film that would today characterize our film and television experiences.

Or then again, we might understand these technologies within a broader framework of 19th century mobility. Here, the tensions between spatial dislocation and temporal simultaneity already broached by the telephone find an imagistic corollary. Many late 19th century illustrations of the anticipated moving image medium include depictions of Western users in Asian or African settings using the telephonoscope and similar imagined technologies to communicate with family and friends "back home." (Figs. 2 and 3) From this perspective, fantasy technologies offer insights into the conditions of colonial expansion and particularly the project of its technological facilitation. In addition to the notion of cultural extension and superimposition, the illustrations of the telectroscope and telephonoscope in situ also occasionally speak to the anxieties of sensory displacement, of being in two places at once. These anxieties seem particularly targeted to the situation of being both at home while away from home-a trope 


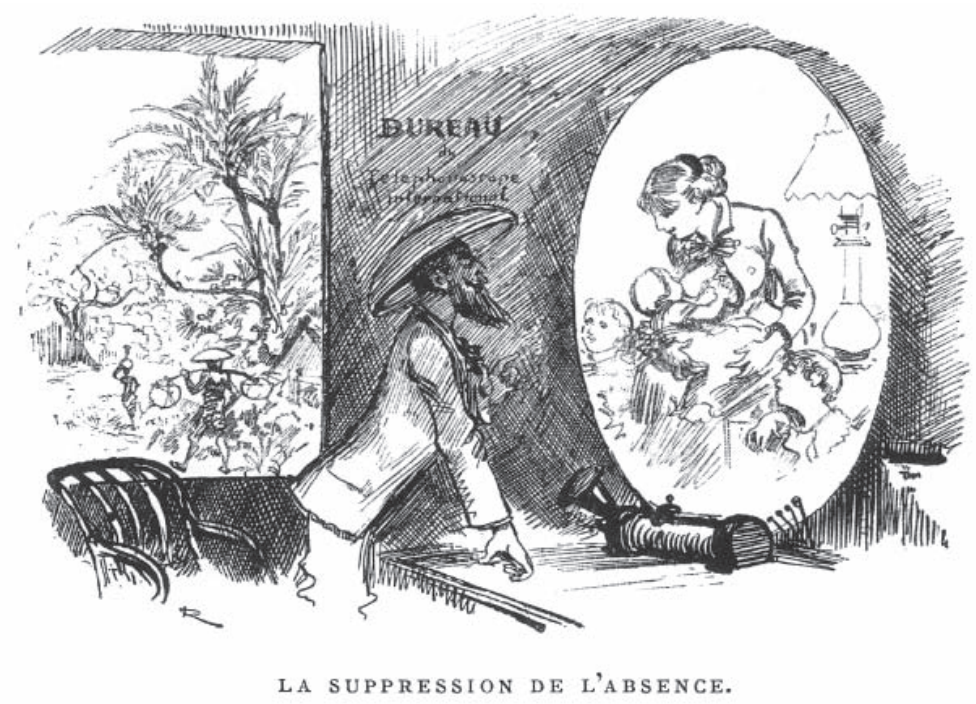

Fig. 2. Imaginary media: the téléphonoscope in a scenario that supports patriarchal presence in geopolitical and domestic settings. (From Albert Robida, Le vingtième siècle, Paris, Éditions Georges Décaux, 1883)

that D. W. Griffith would traumatize and squarely position within the domestic sphere in films like The Lonely Villa (1909), where the telephone is the cause of an anxiety of displacement and the motivation for the film's parallel editing. In this case, the material specificities of one medium (film's reliance on visual sequence through editing) sought to emulate the specificities of another (the telephone's linkage of two spaces in real time), in the process seeking to evoke similar anxieties of sensory displacement.

Or we might consider any number of other entry points-reading the images of these fantasies as articulations of possible image interfaces (widescreen's first appearance, the flat glass oval); or in terms of the domestic and public placements and uses of this audiovisual invention; or in terms of initial thoughts on a new media ensembles in which telephone, phonograph, magic lantern, and other technologies were collapsed; or even in terms of a lexical analysis of the names these fantasy technologies invoked, with their insistence on seeing, distance and electricity. All of these entry points benefit from an analytic frame that privileges intermediality, and attempts to locate these issues within a broader constellation of media technologies, practices, and anticipations.

I would like to narrow the terrain of inquiry and consider these images as evidence of a moment when phantasia meets technè, a moment of conceptual possibility when a medium such as the telephone was still very much in 


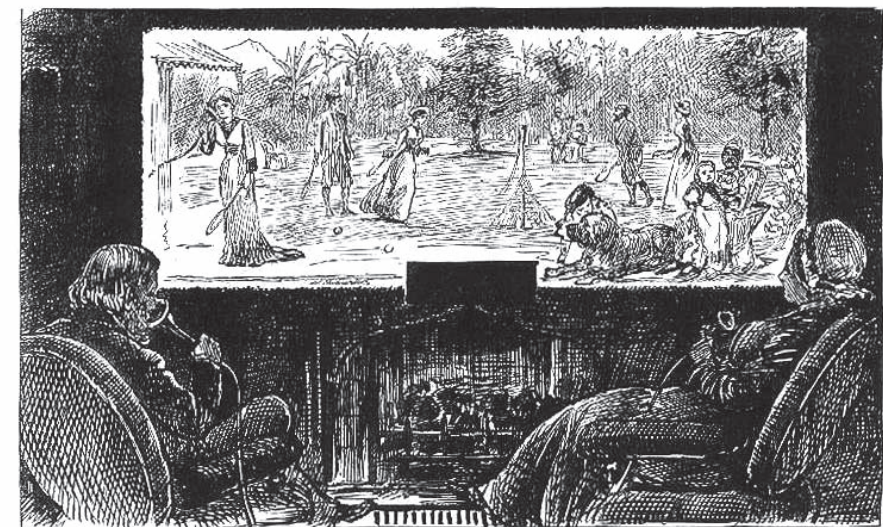

EDISON'S TELEPHONOSCOPE (TRANSMITS LIGHT AS WELL AS SOUND).

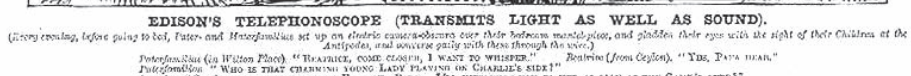

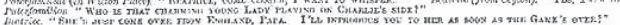

Fig. 3. Imaginary media: point-to-point acoustical communication afforded by the telephone, enhanced by widescreen visual presence via Edison's telephonoscope (drawing by George Du Maurier, Punch Magazine, Almanac for 1879 , No. 75, December 9, 1878).

transition and not yet taken-for-granted and when the "other" moving image medium-film-did not yet exist. But first, it is worth stepping back and considering the deep meanings of the root word of fantasy-phantasia-as a way of coming to terms with the imaginary within which these intermedial constellations appeared and took form. An old and rich concept, its earliest definitions refer simultaneously to two meanings: what can be seen in an object-that is, its appearance and visual qualities; and how objects appear-that is, the reception of visual experience. Traced back to its ancient Greek roots, the term phantasia refers both to the image to be received in the mind as well as to what the mind sees and seeks to present again through word and image. By implication, phantasia, as the free play of aesthesis (the senses), bridges what can be seen with what is seen-and it does this through the imagination. Indeed, it seems to offer a way to invert Husserl's concern about technicization and the modern rupture of the subject and object. By "turning possible worlds into resources for reality," phantasia in this expanded sense seems to go a long way towards bridging the subject-object divide, a bridging that helps to account for the pleasures afforded by "pipe dreams" and fantasies.

Media fantasies and fantastic media have a special place in our thinking about the evolution of related technologies. Particularly at an unstable moment in the social construction (and contestation) of a media technology, a moment 
when we can examine the shifting intermedial assemblages of available technologies together with the seams and cracks that appear, fantastic media offer insights into the period's wished for media capacities. But it is a moment all the more important when considered in terms of the larger cultural framework of the transition from the premodern to the modern, a framework against which this particular set of media technologies, practices, and fantasies all struggled for coherence and meaning. In this context, and set against the particular notion of crisis mapped out by Husserl, the importance of fantasy media technologies-especially technologies that centrally address the relationship of the viewing subject to the world-becomes highly charged. Not only is the mode of the televisual's development ("turning possible worlds into resources for reality") antithetical to the logic that according to Husserl culminated in modernity, but its larger technological project seeks to extend the reach of the subject, to extend and intensify the state of being in the world.

\section{TECHNOLOGIES OF PRESENCE}

If phantasia offers a way to bridge the object-subject divide, the what can be seen with the what is seen, and if fantasies of the televisual can be inscribed within this domain, what of the technical realizations of those fantasies? To begin, let's consider the roots of the other side of the pairing "fantasy technologies," technè. Heidegger seized upon the term, underscoring the point that it (and with it, technology) is not instrumental, but rather is a way of understanding, an attitude that "brings forth" in harmony with nature. He argued that "[ $\mathrm{t}]$ echnology is a mode of revealing. Technology comes to presence in the realm where revealing and unconcealment takes place, where aletheia, truth, happens." ${ }^{8}$ Of course this view may seem at odds with our contemporary sense of the term, and Heidegger seized upon this dissonance in his critique of the modern. Specifically, he found that the modern era misused technè/technology by calling on it to "set upon," "frame," and essentially deform nature. But his preferred notion of technè as "revealing" and "bringing forth" offers some interesting possibilities. Heidegger had no representationalist theory of meaning, no correspondence theory of truth, arguing instead that "phenomenological reflection points out the world rather than representing it." From this perspective, technè takes on great importance in Heidegger's thinking. It offers a way to let things be seen for themselves, and

8. Martin Heidegger, “The Question Concerning Technology," [1954] in The Question Concerning Technology and Other Essays, trans. William Lovitt, New York, Harper and Row Publishers, 1977, p. 13. 
in this sense is very much about "revealing" rather than imposing or recasting things into an image of what they should or might be.

What I like about Heidegger's technè argument, particularly in the context of thinking about media as a technology, is the space that it opens up between presence and representation, between "revealing" and the more familiar hermeneutic project bound up in representation, in which one thing "stands for" another. This distinction seems to parallel the project of the televisual, as a means of connecting a subject in real time with a (contiguous) visual field, of extending being, over and against the project of the cinematic, which re-presents across ruptures in both time and space. Of course, to reduce Heidegger's insight to an applied analysis on the grubby level of ideal-typical visions of proto-television or the telectroscope, or concepts such as televisuality, is to misuse him. But if we consider the fantasies that cohered around the televisual in the 19th century, if we look at the actual of television in the 1930s and 1940s, and if we think about any number of current and near-future applications of the medium, Heidegger's words resonate. Although what we see as a televisual image might appropriately be bracketed off and labeled as representations, how we see seems both far more important and somehow more consistent with pointing out the world, with extensiveness of being, with the notion of presence. 9 These qualities differ profoundly from those inscribed within the cinematic, and Heidegger offers at least one way to begin thinking about a difference that is more fundamental and profound than the usual litany of differences that include domestic delivery, low screen resolution, and program flow.

I am obviously using the term televisual in a sense that has nothing to do with pre-recorded program delivery, i.e., with our dominant experience of television for the past 50 years; rather, the concept shares structures of experience with the camera obscura or the telescope or the telephone or the radio (like television, in an ideal-typical sense, a "live" sense). Although we can certainly talk about our relations to each of these media in terms of representation, in fact we

9. The concept of presence has been explored by a number of scholars. Its media sense ranges from the supernatural, as argued by Jeffrey Sconce (Haunted Media: Electronic Presence From Telegraphy to Television, Durham, Duke University Press, 2000) to the implications of new media technologies, as argued by Vivian Sobchack ("The Scene of the Screen: Envisioning Cinematic and Electronic 'Presence'," in Hans Ulrich Gumbrecht and K. Ludwig Pfeiffer (eds.), Materialities of Communication, Stanford, Stanford University Press, 1994). Readers in search of a rich reflection on the topic should consult Hans Ulrich Gumbrecht, Production of Presence: What Meaning Cannot Convey, Stanford, Stanford University Press, 2004. 
use these media to connect or to point out or to make present, bringing us to an event or the event to us. If we understand the televisual as akin to an electronically extended camera obscura or to the telephone (the inspiration behind the flurry of post-1876 speculations about seeing at a distance), that is, if we think of the televisual as way to extend the viewer's vision to a distant point, and there to engage in real-time, "live" visual (and audio) interaction, the point should be clear. This notion of the televisual in the first place facilitates connection and presence rather than constructing an audio-visual surrogate, which in turn requires interpretation. The telephone, (ideal-typical) television, and camera obscura all operate in "real" time, maintaining the temporal simultaneity of the viewing subject and the world viewed. Moreover, they construct a kind of spatial contiguity, connecting distant spaces through sight lines, wires, or radio waves. By contrast, media such as film, photography and recorded music are predicated upon temporal displacement, bringing images and sounds from the past into the viewer's present. Because of this temporal disjunction, they have the privilege of premeditation. They afford vast opportunities for creative intervention, for care in textual construction and the fine-tuning of signifying practices, resulting ultimately in a conscious and inescapable project of re-presentation. Textual complexities and even such simple ordering structures as the beginning and end can be taken for granted in a domain where temporal rupture affords the time, space and even the necessity for reflection, creative intervention, and the textual construction of meaning. Such strategies are unavailable to the camera obscura, whose content begins and ends with the presence of the viewing subject rather than the textual requirements of filmic structure.

The difference between these two positions can be illustrated through an historical example. Consider the German Post Ministry's plans for post war television in Greater Germany and the occupied lands, drafted in 1943. ${ }^{10}$ The Post Ministry, long in competition with the Propaganda Ministry, hoped that television would offer a way to dislodge its much-despised partner in broadcasting. ${ }^{11}$ The Post, which controlled technical infrastructure and live news feeds, drew up plans for a live cable television news network. It argued that control of the

10. Germany began daily television broadcasting in March 1935 and continued until nearly the end of the war. This development was remarkable for the variety of ideas about the medium, many of which were backed by political and industrial constituencies, and deployed.

11. Besides representing two very different institutional cultures, one, professional and bound by an engineering ethic, and the other defined by ideological fervour, the two ministries constantly fought over the division of broadcast license fees. 


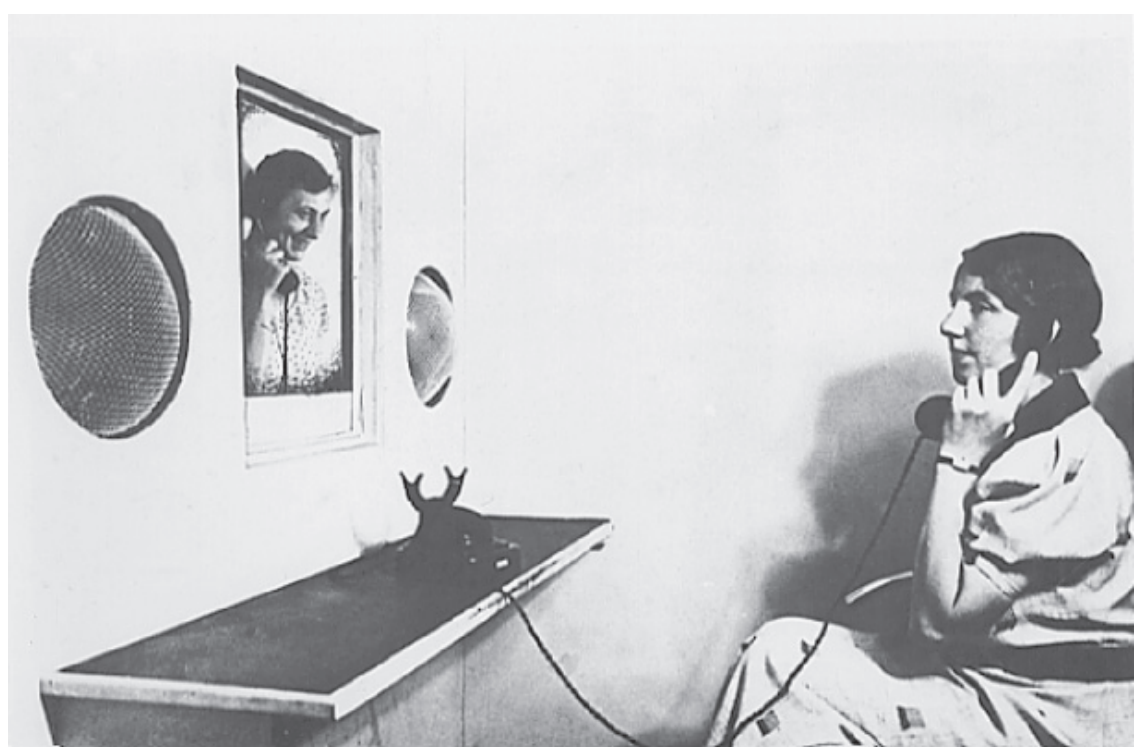

Fig. 4. Promotional photo for Germany's television-telephone service which connected post offices in major cities during much of the National Socialist era (ca. 1939).

rhythms and flow of daily life through a live feed would render the need for persuasive pre-produced programming content (the domain of the Propaganda ministry) redundant. In this case, control of the nation's neural networks, the ability to direct its gaze and forge a live connection between viewer and world viewed, provided the double advantage of superceding the impact of whatever propaganda program texts might be cast before the viewing public's eyes and perhaps even more importantly, served the project of electronically forging a Volkskoerper-a nation, a people, bound together by the synchronicity of experience. The responsible postal authorities were acutely aware of the added value of bridging the gap between subject and object, and the live televisual link promised to conjoin both in a manner that far superceded the capacities of storage-based media.

Given this conception of television as akin to a neural network rather than a home provider of pre-packaged texts, it is perhaps not surprising that between 1936 and 1944 the German postal authorities also developed a nation-wide network of telephone-television exchanges, literalizing the medium's embrace of concepts such as "bringing forth" or "making present." (Fig. 4) Of course, one can argue that audiences, whether in the telephone-television booth or watching a constantly live television feed, ultimately looked at a screen and saw representations of their interlocutors; indeed, one could make the same argument about 
the images seen in a telescope or camera obscura or the sounds heard on a telephone. But while a heuristic possibility, this is to miss a more evident mode of engagement, the ability to extend aspects of one's being or gain selected sensory access to a distant event, an engagement that draws upon a sense of presence and interaction, rather than analytic distance and the need to process the distance between the signifier and the signified. Like the rabbit-duck illusion, where we can see either animal in the image but not both at the same time, either mode of engagement is possible, but only in a mutually exclusive manner. But unlike the rabbit-duck example, we gravitate towards using the medium in order to see what is on the other side, to bridge space and time, to extend presence and scope of action, to connect.

The example of television in National Socialist Germany is a particularly intriguing one, since it seems to offer evidence of a technology deployed in what Heidegger would see as the premodern spirit of technè. By "revealing" rather than "standing for," by "pointing out" the world rather than "representing it," this historical deployment of the televisual both harkens back to the 19th century notion of the telectroscope and telephonoscope, and stands as a sharp counterpoint to the cinematic, which would seem more concerned with "standing for" and "representing." The actual deployment of this distinctive and "premodern" sense of the medium in Germany is a story not without some ambivalence. As Jeffrey Herf and others have argued, Germany had a complex and contradictory relationship with modernity during the Third Reich, selectively deploying it in a project that seemed fundamentally and even perversely romantic. ${ }^{12}$ Herf's notion of "reactionary modernism" seems an accurate descriptor of the Post Ministry's plans, or of the telephone-television network, or even of the use of television as a real-time guidance system for rockets and torpedoes as deployed by the Air Ministry. ${ }^{13}$ (Fig. 5) The sense of ambivalence certainly extends to some of Heidegger's notions of being and his critique of the modern. But it also speaks to the larger point Husserl makes about Technisierung and the crisis of subject-object relations as a defining component of modernity. Consistent with the 19th century's

12. Jeffrey Herf, Reactionary Modernism: Technology, Culture and Politics in Weimar and the Third Reich, Cambridge, Cambridge University Press, 1986.

13. For more details on National Socialist uses of television, see William Uricchio, "Television as History: Representations of German Television Broadcasting, 1935-1944," in Bruce Murray, Christopher Wickham (eds.), Framing the Past: The Historiography of German Cinema and Television, Carbondale, Southern Illinois University Press, 1992, p. 167-196 and William Uricchio (ed.), Die Anfange des deutschen Fernsehens: Kritische Annaherungen an die Entwicklung bis 1945, Tubingen, Max Niemeyer Verlag, 1991. 


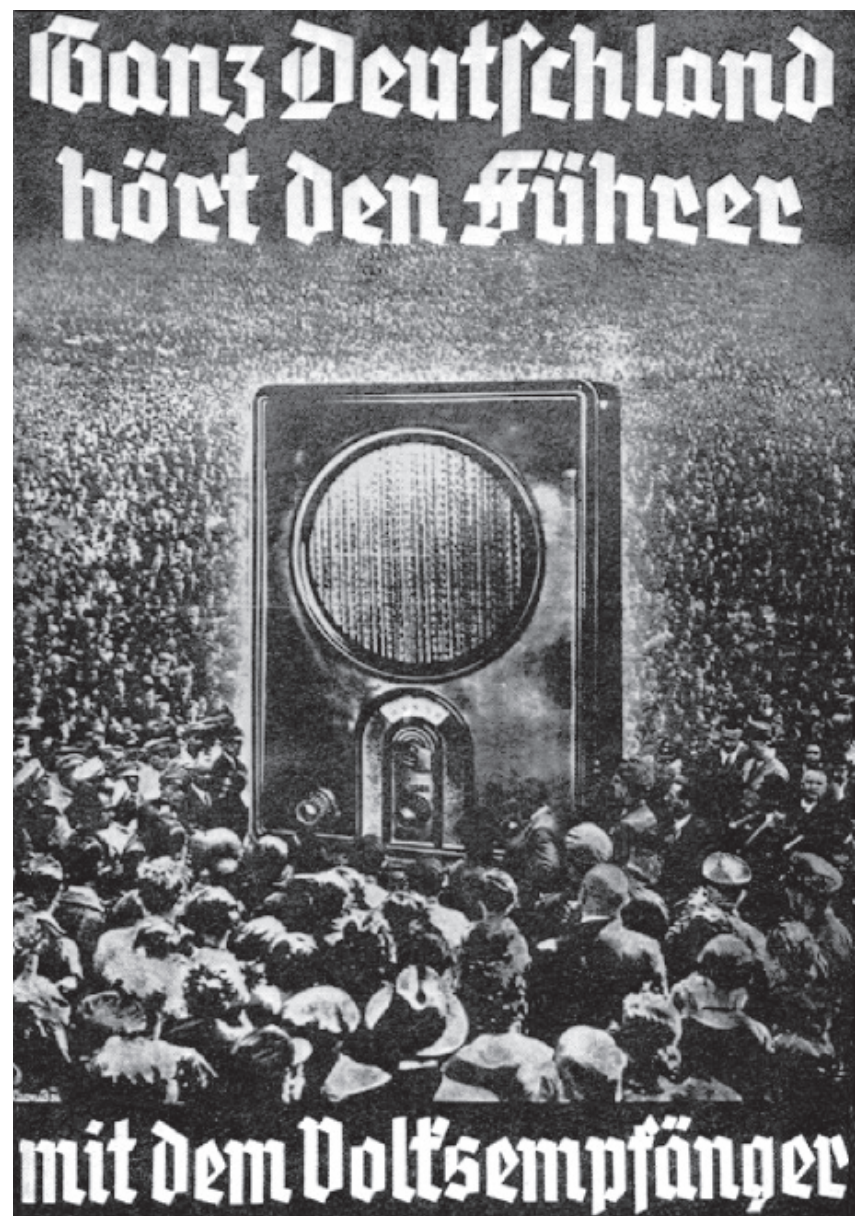

Fig. 5. Promotional poster for National Socialist German radio as a means of linking the nation with its leader, a goal that NS television developers sought to serve. The text translates: "All Germany hears the Führer on the People's Receiver" (ca. 1943-1945). 
fantastic notions of live television, German television authorities sought to activate links between subject and object, recasting this relationship in terms of the viewer and the nation. ${ }^{14}$

Given the opportunities afforded by the televisual as an imagined (and ultimately realized, as the German case shows) media technology, the question is whether we might consider harnessing technè (in Heidegger's sense of a mode of revealing, part of the project of "pointing out") to the project of phantasia (as a bridge between object and subject). That is, whether we might consider these imaginary media technologies as occupying a privileged space in our larger thinking about media (both real and ideal-typical). Rather than marginalized images of the fantastic, or as conceptual dead ends or unfulfilled desires, might not these notions of the televisual speak to a distinctive if underappreciated moment in the construction of the modern? Drawing on a constellation of mid-to-late 19th century media technologies (both real and imagined), they might be seen as embodying the romantic ethos and using technology to "point out" rather than to "represent." That they articulate this vision of techne from the vantage point of phantasia only strengthens the case. This perspective, in any event, might offer a way to recover the profound ambivalence of at least fantasy televisual technologies vis-a-vis the charges faced by cinema (as synecdochial for mechanical and industrial media), namely that they served as agents of the "loss" bound up with modernity. And it offers a way to better position and possibly articulate the televisual's difference from the cinematic.

Fantasies of the televisual need to be read against a background of contestation and change (the modern and premodern, subject-object divides, and the rest). Poised at the transition between two systems, these fantasies are sites of ambivalence, perhaps contradiction as well, but insight nevertheless. As historical artifacts, they formed part of a discursive positioning for subsequent media forms - from the early cinema to the recurrent promise of picture phones and even to our current dreams of holodecks. But locating the desire for "presence" within a premodern project, and signaling the televisual's capacity to deliver presence (and cinema's inability to do so), helps to clarify the ontological differences between these two media, and moreover, to link this aspect of television's ontol-

14. Lest it be thought that only National Socialist deployments of television explored this link of viewer and world, it is useful to recall the role of television in disasters such as 9/11 or festivities such as the World Cup, moments where viewers and events are bound together in live events. 
ogy to a particular epistemic regime. By the same token, pushing the argument might also offer another way to consider the modernity of the cinematic.

Attempting to think through the televisual with the help of the 19th century's fantastic predictions and the early-2oth-century patterns of actual deployment serves to amplify an underlying if virtually extinguished dimension of contemporary television: the notion of liveness, of temporal simultaneity so important to presence. Recently in the US, exposure of Janet Jackson's breast was a sufficient cause to effectively outlaw live television; all "live" feeds are now subject to a several second delay. Indeed, what I have been arguing as the televisual's defining engagement with presence and extension has been so thoroughly excised from the current construction of television that its continued manifestations-surveillance video, medical video, video-based missile guidance systems, even webcams and the like-seem to fall outside of most conceptions of television as a medium. Any number of arguments can explain this situation, from cultural conditioning and a preoccupation with narrative texts, to the difficulties of sustaining a business model based on live feeds, to a displacement and repositioning of these desires through new media technologies. But putting the "reality" of contemporary television into the larger historical perspective suggested in this essay also opens up the possibility of reading the broadcast television era as itself something of a deformation, a 50-year collusion of corporate and governmental interests that essentially served to reify one of the medium's many possible constructions. With the slow move towards digital broadcasting and the rather faster development of alternate, computer-and telephone-based technologies for seeing at a distance, we can still see that elements of the old dream survive. Repositioning television from a contributing factor in an already rich intermedial environment, to an intermedial composite in itself, offers a way both to recover threads of continuity between the 19th and 21st centuries, and to situate those threads within the deeper structures of an epistemology of mediation, the ways that media give us access to and knowledge of the world. 